$\mathrm{Na} \times \mathrm{Ca}_{3}-0.5 \times \mathrm{Ge} \mathrm{O}_{3}(\mathrm{x}=2.5,3)$ の構造について

\title{
西文人（埼玉工大），竹内 鹿夫（日大）
}

メ夕珪酸塩として $\mathrm{Na}_{2} \mathrm{O}-\mathrm{C}$ a O - S i O 2 の三成分系は、材料科学的に重要な物質 (とくにガラス工学上)であり大里、竹内、牧らによって近年勢力的に研究されている。 我々は長年 $\mathrm{C}_{3} \mathrm{~S}\left(3 \mathrm{CaO} \cdot \mathrm{S} \mathrm{iO}_{2}\right)$ P $\mathrm{C}_{3} \mathrm{G}(3 \mathrm{CaO} \cdot \mathrm{GeO} 2)$ を手がけてい るがそれによるとS i G e で置換した場合には polymorphppolyty pe 的に大变興味深い相違点が観察されている。そこで我々は、 $\mathrm{Na}_{2} \mathrm{O}-\mathrm{C}$ a O - G e O の三成分系を用いて、フラックス法で 3〜4種類の新物質を合成し、さらにそれらの構造 定解明し、大里等が解いたメ夕珪酸㦈の構造と比較し、その類似点および相逗点を結晶化 学的な見地より研究した。らなみに今回は2種類の物質（Ｒ３ｍとP3，21）について 報告するが、それらの結晶学的なデータは右表にある。強度測定は四軸型自動回折形( S y n t e x P 21) を使用しMoK $\alpha$ で 晶については 708 個のB r a g g 反射在使用し Ful1-Matrix最小自乗法で $\mathrm{R}=5.1 \%$ まで精密化した。続いてP 3121の結晶は、

2142 個の反射を使用しR=5.9\%まで精密化

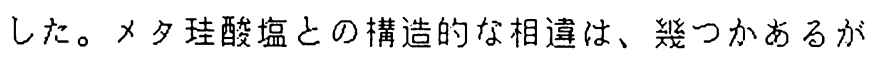

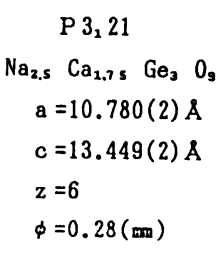
例えば我々のP 3，21の結晶には $\mathrm{M}$ （２２）という 新しいサイトがあるがメ夕珪酸塩にはない等であるが 詳細は学会で発表する予定で尚る。

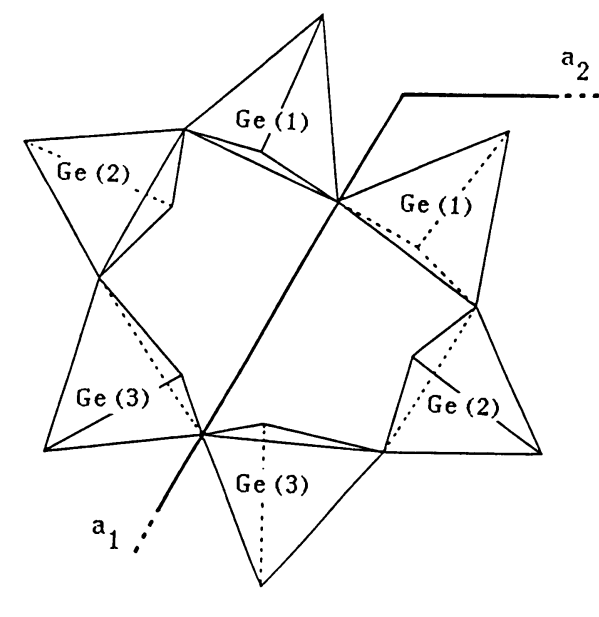

Deformed six-membered ring of P3, 21

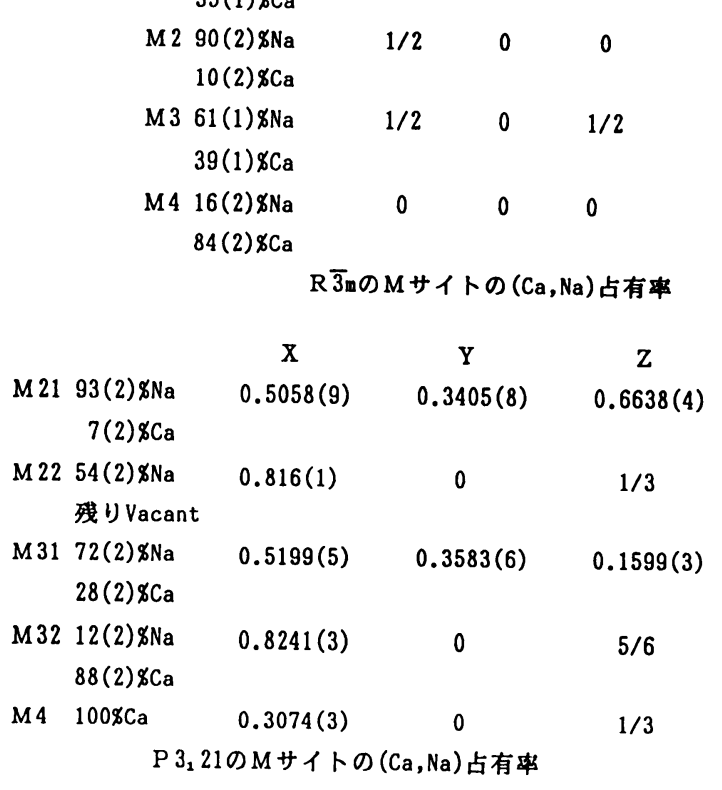

